\title{
Oil a Blessing or Curse: A Comparative Assessment of Nigeria, Norway and the United Arab Emirates
}

\author{
Ali Elwerfelli, James Benhin* \\ Faculty of Business, Plymouth University, Plymouth, UK \\ Email: ${ }^{\star}$ james.benhin@plymouth.ac.uk
}

How to cite this paper: Elwerfelli, A. and Benhin, J. (2018) Oil a Blessing or Curse: A Comparative Assessment of Nigeria, Norway and the United Arab Emirates. Theoretical Economics Letters, 8, 1136-1160. https://doi.org/10.4236/tel.2018.85076

Received: December 24, 2017

Accepted: April 17, 2018

Published: April 20, 2018

Copyright ( $\odot 2018$ by authors and Scientific Research Publishing Inc. This work is licensed under the Creative Commons Attribution International License (CC BY 4.0).

http://creativecommons.org/licenses/by/4.0/

\section{cc) (i) Open Access}

\begin{abstract}
Oil booms have brought unprecedented wealth and development to some countries while in others this has not been the case. The latter is attributed to the resource curse phenomenon which has been explained by the Dutch disease and more recently by poor quality institutions. This paper is a three country comparative assessment of how countries have utilised their oil revenues and the extent to which key policy environments, such as institutional and political aspects, may have influenced different outcomes. Evidence shows that in Nigeria, oil has been more of a curse because institutions have not been strong enough to efficiently manage the vast oil revenue to have a positive impact on the economy and for the benefit of its people. In Norway, the management of oil resources reflects the view of decision makers that the resources belong to current and future generations, and therefore the development of the industry should benefit both generations. Appropriate institutions and policies such as the Petroleum Pension Fund, Sovereign Wealth Fund, a more diverse economy and a fiscal rule for controlling, and more targeted, expenditures were implemented. These, in addition, to a very stable democratic political environment and effective legal system meant that oil has become a blessing to Norway. The UAE has a similar but different approach to Norway, by using oil as a basis for sustained development. It has a Sovereign Wealth Fund, and focuses on distribution of the oil-wealth and investment in social and economic infrastructure leading to a more diverse economy. The nature of its political stability, although essential to avoiding the curse, is different from Norway's and there is potential for tension and conflict. For developing countries in general, good governance, accountability, high government effectiveness, appropriate regulations and anti-corruption policies will help link natural resources with high sustained economic growth and turn the resource from a curse to blessing.
\end{abstract}




\section{Keywords}

Natural Resource Curse, Dutch Disease, Institutions, Nigeria, Norway, UAE

\section{Introduction}

Oil discoveries, and subsequent booms in the economy, have brought unprecedented growth and development to many previously poor countries. However, others have experienced what has been referred to as the resource curse, a concept which points to the contradictory effects of natural resource abundance on economic development [1] [2] [3] [4]. Weak economic performance of some oil rich countries indicate that natural resources are often more of a curse than a blessing for these countries. The resource curse examines the negative effects of large quantities of natural resources on economic growth from an economic and political perspective. The term "resource curse" was first used in the formal economics literature by Auty [5] to describe how countries rich in natural resources were unable to use that wealth to boost their economies and how, counter-intuitively, these countries had lower economic growth than countries without an abundance of natural resources. The concept was later the subject of extensive research including the studies carried out by Sachs and Warner [6] who found the existence of a negative association between natural resources and growth.

The appreciation of the real domestic exchange rate, known as the Dutch disease, has been noted as the main reason for the poor economic performance of oil rich countries Dutch disease manifests itself when labour and capital migrate from other sectors to the booming sector, causing real exchange rates to rise as a result of the booming economy. This presents a scenario where all other sectors of a country's economy suffer owing to the rapid growth in income from natural resources, which in turn creates higher costs and a reduction in competitiveness for domestically produced goods and services in previously effective productive sectors. This happens because increased revenues from natural resource exports tend to increase the value of the exporting nation's currency. This makes the country's other exports, such as agricultural products and manufactured goods, more expensive and therefore less competitive in world markets. The economy thus becomes over reliant on the natural resources that it is exporting and this can be particularly damaging, if for any reason, there is a drop in world prices for those natural resources [7] [8] [9].

However, long lasting ineffective institutions, corruption and rent seeking behaviours, are considered to be additional major causes [10] [11]. Indeed, natural resources are not always a curse; they can be a blessing and lead to high economic growth and efficient economic performance for countries with strong institutions [12].

In this paper we undertake an assessment and a comparative analysis of three 
countries, Nigeria, Norway, and the United Arab Emirates (UAE), regarding the effects of oil windfalls, how these petroleum exporters have utilised their oil revenues, and the consequences of their respective government policies. In other words, the extent to which key policy environments, such as institutional and political aspects may have influenced different outcomes resulting from oilabundance in the respective three countries. The paper concludes that, in some countries, much of the potential benefit of the windfalls has dissipated, and explains why some oil producing countries may have a weaker, less diversified, and more dependent economy, despite the significant additional revenue generated from oil exports. It is also suggested that natural resources alone will do little to promote economic development. Countries need sound economic management and it is imperative that they address institutional and political factors that negatively affect appropriate and prosperous policy choices. Market processes are needed to help allocate public resources, and governments and other key establishment individuals who are responsible must take full account of the risks when formulating plans for development and selecting projects.

The three countries were selected owing to the differing effects of oil wealth on their economic development. The objective is to broaden the scope of the analysis of the potential effects that oil wealth can have on a country, and further emphasise key variables that may or may not lead to the resource curse phenomenon. Nigeria is used as a classical example of negative effects of oil on social and economic development. Norway is an example of a successful case of escaping the potential "curse" and utilising oil reserves into an economic "blessing". The UAE provides an impressive case of oil-led development yet experiencing enormous social and economic difficulties.

Each case study is structured as follows: a brief presentation of the history of oil discovery and subsequent transformations, as well as the analysis of basic economic and social data such as growth, unemployment, and poverty rates. The ratio of the oil sector's revenue to GDP and total exports compared to other industry sectors are seen as the key determinants of whether a country is over-dependant on oil revenue or not, whilst the diverse structure of the economy is viewed as being an indicator of positive developmental performance and vice versa. In each case study, the major causes and factors of either negative or positive impact of oil on economic development is analysed, with a focus on the institutional environment.

\section{Nigeria: The Classic Case of a Resource Curse}

Nigeria is the largest oil producer in Africa and the sixth largest exporter in the world. Yet, Nigeria is unanimously presented in the literature as the classical exemplifier of the resource curse. The paradox is evident just by looking at some statistics. The country produces 2.4 million barrels of crude oil daily and according to the Oil \& Gas Journal [13], it holds the tenth largest proven oil reserves in the world, with the second largest reserves in Africa after Libya. The 
country's proven oil reserve as of 2015 stood at 37.14 billion barrels [14]. But according to the UN's 2007 Human Development Index (HDI) Nigeria was amongst some of the poorest nations in the world and is ranked 158th out of 177 countries assessed in the index [15]. This position has not change significantly in the last decade.

Before the oil boom era in the early 1970's, the government was very dependent on revenues from the agricultural sector. Nigeria was one of the key exporters of diverse agricultural products, such as groundnut, cotton, cocoa, palm oil, timber, hides, and skins, which are used in most manufacturing industries domestically and internationally. Nigeria's agricultural industry used to employ over $70 \%$ of the population [16] and was the world's largest palm oil exporter [17].

The agriculture industry in Nigeria's current economy has effectively been replaced by the oil industry in terms of revenue. Despite the significant oil revenue, the structural development has been poor and has even worsened the administrative position in Nigeria due to the level of corruption and oil policy implementation. The oil wealth was not invested to support the agriculture nor manufacturing sector, which has led to neglect and has therefore attracted factors of production away from agriculture and manufacturing, leading to a manifestation of what is termed as Dutch disease resulting in a resource curse [7].

In general, before the oil-boom, the economy was characterised by the predominance of subsistence and commercial activities, with a narrow production base, ill-adapted technology; lopsided development owing to the bias of public policies, openness and excessive dependence on external factor inputs, continuous siphoning of surpluses from the economy, and especially weak institutional capabilities. The discovery of oil in 1956 and its subsequent exploitation transformed Nigeria's political economy radically over half a century [18]. During the first decade ofits discovery, oil did not play a significant role in the economy, as it only amounted to less than $10 \%$ of GDP. Yet agriculture, as the key productive sector of the Nigerian economy since the 1970s, was gradually crowded out by the growing oil sector, and the development of non-oil sectors was almost non-existent. In recent years, oil has provided approximately $80 \%$ of the government revenue and 95\% of export earnings [19].

As indicated before, Human Development Indicators are quite low in Nigeria with the average HDI value being as low as 0.515 in 2014 (Table 1) resulting in the country being ranked at 152 out of 188 countries. In spite of the fact that, between 2005 and 2014 Nigeria's HDI value increased by about 10\% from 0.467 to 0.514 , and over 1980 and 2014 life expectancy increased by 7.2 years, mean years of schooling increased by 0.7 (2005-2014), and expected years of schooling increased by 2.3 years, Nigeria's HDI value has placed the country in the low human development group. This is evidence of the serious negative effect of oil wealth over Nigeria's economy, which has been caused by the lack of promotion of a higher standard of living, education, income, and quality of life. Hence, the natural resources in Nigeria could be deemed as more of a curse than a blessing. 
Table 1. Nigeria-Selected Human Development Indicators (HDI).

\begin{tabular}{lccccc}
\hline Year & $\begin{array}{c}\text { Life expectancy at Expected years of } \\
\text { birth }\end{array}$ & $\begin{array}{c}\text { Mean years of } \\
\text { schooling }\end{array}$ & $\begin{array}{c}\text { GNI per capita } \\
\text { (2011 PPP\$) }\end{array}$ & HDI value \\
\hline $\mathbf{1 9 8 0}$ & 45.6 & 6.7 & & 2833 & \\
$\mathbf{1 8 8 5}$ & 46.4 & 8.6 & & 2451 & \\
$\mathbf{1 9 9 0}$ & 46.1 & 6.7 & & 2743 & \\
$\mathbf{1 9 9 5}$ & 45.1 & 7.2 & & 2529 & \\
$\mathbf{2 0 0 0}$ & 46.6 & 8.0 & & 2378 & \\
$\mathbf{2 0 0 5}$ & 48.7 & 9.0 & 5.2 & 3606 & 0.467 \\
$\mathbf{2 0 1 0}$ & 51.3 & 9.0 & 5.2 & 4825 & 0.493 \\
$\mathbf{2 0 1 1}$ & 51.7 & 9.0 & 5.5 & 4926 & 0.499 \\
$\mathbf{2 0 1 2}$ & 52.1 & 9.0 & 5.7 & 5018 & 0.505 \\
$\mathbf{2 0 1 3}$ & 52.4 & 9.0 & 5.9 & 5166 & 0.510 \\
$\mathbf{2 0 1 4}$ & 52.8 & 9.0 & 5.9 & 5341 & 0.514 \\
\hline
\end{tabular}

Source: [22].

The overdependence of the economy on oil has had detrimental consequences on the social wellbeing of its citizens. The agricultural sector, which was once productive, is now unable to produce enough food for its domestic market, making the country reliant on food imports. The social infrastructure of the country is in disarray [20], and poverty levels are dire. According to UN statistics, 36\% of Nigerians lived under the poverty line in 1970. In contrast, in 2007 around $70 \%$ of citizens lived on less than $\$ 1$ a day, and $92 \%$ lived on less than $\$ 2$ a day [15]. The proportion of the population living below the poverty line increased significantly between 1980 and 2004. According to The National Bureau of Statistics [21], 69\% of Nigerians were living in absolute poverty in 2010 (Table 2(a) \& Table 2(b)). Nigeria has the largest economy in Africa but it is affected by its limited infrastructure, particularly its transport and energy infrastructure, which imposes serious limitations on the country's economic growth potential. Significant challenges, such as power shortages, are evident in the electricity sector and this has negatively impacted industrial growth. Economic growth in Nigeria is therefore constrained by inadequate infrastructure, electricity, incentives and policies that promote private sector development, and poor access to quality education. Approximately a quarter of the adult population lacks formal education [22].

In addition, unemployment in Nigeria has become one of the most critical problems facing the country. According to statistics from the [23] [24], Nigeria's overall unemployment rate consisted of $23.9 \%$ of the total labour force in 2011, indicating a sharp increase from $14.9 \%$ in 2008 as shown in Table 3. When disaggregated, $17.1 \%$ of unemployment is in urban areas and $25.6 \%$ is in rural areas.

Given the country's enormous resources, it is puzzling that such a huge proportion of the populace lives in poverty, and there is high unemployment, low 
Table 2. (a) Relative poverty in Nigeria (1980-2010); (b) National poverty incidence in Nigeria (2003/2004 and 2009/2010).

(a)

\begin{tabular}{cccc}
\hline Year & $\begin{array}{c}\text { Poverty Incidence } \\
(\%)\end{array}$ & $\begin{array}{c}\text { Estimated Population } \\
\text { (Million) }\end{array}$ & $\begin{array}{c}\text { Population in } \\
\text { poverty (Million) }\end{array}$ \\
\hline 1980 & 27.2 & 65 & 17.1 \\
1985 & 46.3 & 75 & 34.7 \\
1992 & 42.7 & 91.5 & 39.2 \\
1996 & 65.6 & 102.3 & 67.1 \\
2004 & 54.4 & 126.3 & 68.7 \\
2010 & 69.0 & 163 & 112.47 \\
\hline
\end{tabular}

Source: [22].

(b)

\begin{tabular}{cccc}
\hline Year & $\begin{array}{c}\text { Absolute Poor } \\
(\%)\end{array}$ & $\begin{array}{c}\text { Relative Poor } \\
(\%)\end{array}$ & US\$ Per Day \\
\hline $2003 / 04$ & 54.7 & 54.4 & 51.6 \\
$2009 / 10$ & 60.9 & 69.0 & 61.2 \\
\hline
\end{tabular}

Source: [21].

Table 3. Nigeria unemployment rates (2005-2011).

\begin{tabular}{ccccccccccccc}
\hline Year & 2000 & 2001 & 2002 & 2003 & 2004 & 2005 & 2006 & 2007 & 2008 & 2009 & 20109 & 2011 \\
\hline $\begin{array}{c}\text { Unemployment } \\
\text { rate (\%) }\end{array}$ & 13.1 & 13.6 & 12.6 & 14.8 & 13.4 & 11.9 & 12.3 & 12.7 & 14.9 & 19.7 & 21.1 & 23.9 \\
\hline
\end{tabular}

Source: [23] [24].

industrial and agricultural development, and generally poor economic and social indicators. This vast incidence of poverty and poor indicators in the midst of significant wealth has been linked to the endemic corruption in the country, as it involves the stealing of resources that would have otherwise been invested in providing wealth-creating infrastructure for the country's citizens. The corruption has also been sustained by the high political instability and poor management of the oil wealth.

The windfall of oil revenues into the federal budget raised expectations and led to excessive government spending based on unrealistic revenue projections, in particular in the 1970s and 1980s. This led to a significant increase in inflation (Figure 1), slowed down economic growth, and prevented development of the non-oil sector.

As large amounts of public finances were channelled into private income, there followed a huge increase in private consumption. The pattern of that consumption was to prioritise imported goods, while locally manufactured products were treated as inferior which in turn lowered demand. Therefore, a low demand for domestic products meant that manufacturers reduced their demand for labour which led to a rapid fall in domestic manufacturing [15]. Oil revenues in 


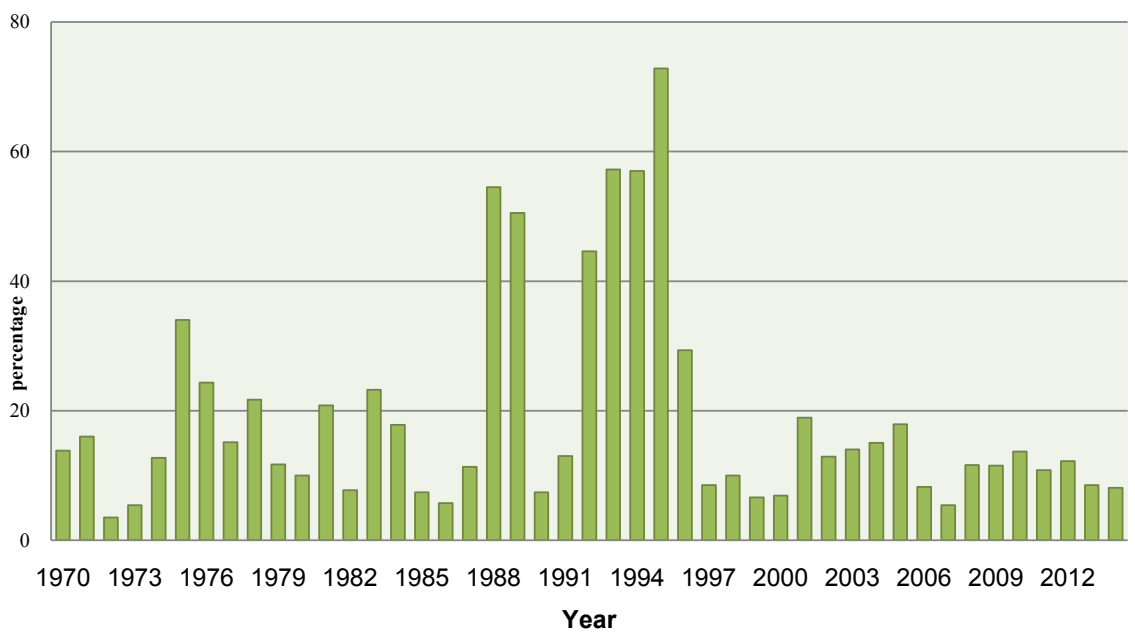

Figure 1. Nigeria inflation rate (CPI measurement) (1970-2014). Source: [25].

the long-run had negative effects on agriculture and manufacturing growth, which is sufficient evidence of the presence of Dutch disease within Nigeria. The booming oil sector crowded out the previously productive agricultural sector and suppressed the development of non-oil industries [16]. The oil boom created difficulties for both agriculture and manufacturing by producing an overvalued exchange rate; this, in turn, made Nigerian agricultural and manufacturing exports less competitive on international markets, resulting in a reduced demand for those products. Also, Nigerian elites were politically and ideologically opposed to trade liberalisation, and the combination of overvalued exchange rates and trade restrictions kept growth in the manufacturing and agricultural sectors low [26]. Exports from these sectors were further hampered by unfavourable domestic pricing policies. The Nigerian government could have devalued the currency to support these sectors, but it chose not to do so. The government could have provided further incentives to the non-oil export sector, and simultaneously prevented significant rises in inflation, by liberalising its restrictions on trade. In addition, the governments made low investments, if at all, in the development of infrastructure, non-oil sectors and education

The explosion of the country's debt could also be attributable to the oil boom and inappropriate public finance planning of the revenue generated from oil exports. From the early 1980 's, when foreign exchange earnings plummeted as a result of the collapse of prices in the international oil market, Nigeria began to experience debt problems due to inappropriate public finance planning. External loans began to be acquired randomly without any form of due diligence. The debt crisis, which is the combination of accumulated debt, had imposed a huge burden on the Nigerian economy. Nigeria's public debts pushed its debt profile extremely high, and it has relied on that public debt to finance its development projects over the last two decades. The debt burden has clearly been a constraining factor on rapid economic recovery, growth and development, with the debt increasing at an alarming rate. Instead of allocating resources to crucial de- 
velopment projects, the burden of high public debt has caused the channelling of funds into debt servicing [27] [28]. The mismanaged international oil price boom and bust cycles has led Nigeria into enormous foreign borrowing. Before the oil boom, Nigeria's national debt was very low. Between 1970 and 2004, the nation's external debt alone increased from US $\$ 836$ million to US\$38 billion [15]. Nigeria's total national debt at the end of 2016 stood at US $\$ 31$ billion, which was equivalent to $10.2 \%$ of GDP [29] As the total national debt to GDP is far below the recommended threshold of $40 \%$ for similar economies, Nigeria debt distress is considered to be of relatively low risk internationally [30] however the debt burden is still relatively high.

Not only were a large percentage of oil revenues being channelled into debt servicing, enormous sums of money were extracted from Nigeria's national treasury with no indication of where the money went. Some analysts estimate that over US $\$ 217.7$ billion could have been stolen from the treasury since the beginning of oil exportation in the country [31]. Funds are stolen from the state through corruption, tax evasion, and illegal transfer of profits by multinationals. According to the Global Financial Integrity [32] [33], estimates of more than US $\$ 157$ billion had left the country illicitly within the last decade. This high loss of revenue prevents Nigeria from being able to meet its economic development goals.

It has been observed that Nigeria is the most corrupt country in the world, as it ranked 177 from 191 countries with a score of just -1.27 out of 2.5 in 2014 [34]. Figure 2 shows that Nigeria's average control of corruption index was -1.13 with a minimum of -1.33 in 2002 and maximum of -0.81 in 2008. Corruption in Nigeria seemed to be everywhere. The health and medical services are considered to be the least corrupt of the government institutions, but even they are considered to be very corrupt by $41 \%$ of Nigerians [35]. Therefore, corruption is one of the factors responsible for negative effects on the economy, and the existence of the resource curse phenomenon. The issue of corruption and social injustice range through bribery, poor wages, nepotism, discrimination, poverty, poor political leadership, and poor education.

Rent-seeking became the most "prominent activity" in Nigeria [15]. Consequently, regional and ethnic competitions for control over oil revenues transformed the country's political system into some sort of institutional patronage

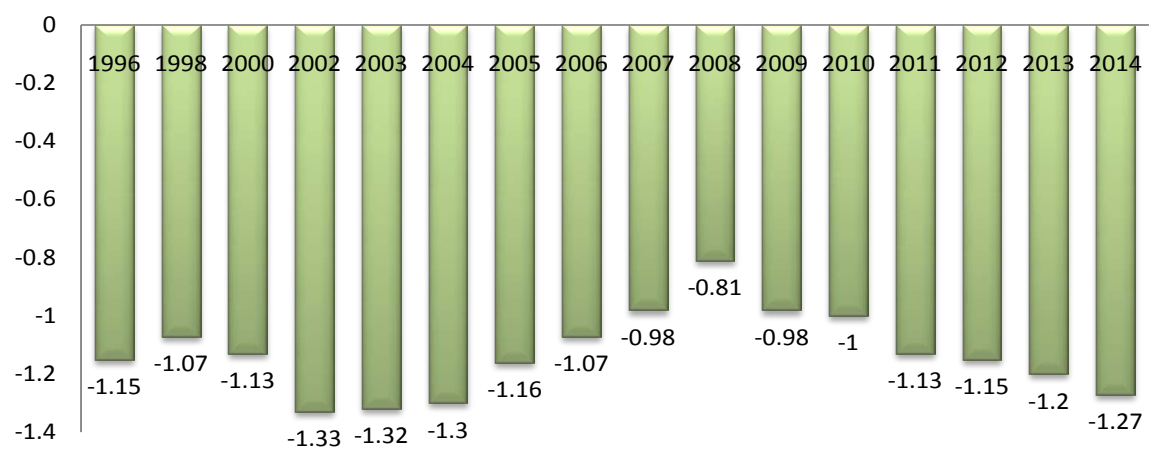

Figure 2. Nigeria Control of Corruption index (1996-2014). Source: [34]. 
[36]. Although recent political environment has been more stable, for years the country was governed by military regimes, which frequently changed through military coups. But the military officers themselves were vulnerable to ethnic antagonism, leading to countercoups and ensuing civil wars. The military intervened with a coup in 1966. The turbulent military interventions of 1966 yielded nearly a decade of rule by General Yakubu Gowon. He sought to address problems of national unity, and presided over the early years of the petroleum boom [37]. Increased evidence of corruption amid the oil windfall prompted further intervention by the military force. General Murtala replaced Gowon in July 1975, promising rapid movement of Nigeria towards transition to civilian rule, greater economic probity, and administrative reform. Six months later, Murtala was killed in a failed coup attempt and was replaced by the second in command, Olusegun Obasanjo, who continued the regime's programmes. Apart from overseeing the transition to civilian rule, the Murtala-Obasanjo government advanced an ambitious programme of state-led industrialisation and expansive social provisions, in addition to overseeing the transition to civilian rule [38].

There were a succession of military regimes promising a return to democracy between 1966 and 1976, but political reform was deferred until 1979 when civilians regained power from General Obasanjo. The new civilian regime's ability to govern quickly diminished due tomassive corruption, mismanagement, political deception, and epidemic violence, which undermined the legitimacy of the democratic system in the eyes of the public. Once again, the armed forces stepped in with promises of remedial action. After four years, General Buhari terminated the civilian governmentin 1983 on the grounds that his regime would mitigate corruption. Buhari's regime instigated a new era of military dominance that proved more corrosive to the country's capabilities, economic development, and social stability than the previous military leaders.

Despite their reformist pretensions, military regimes have proven no more capable than the civilians at resolving central challenges of state building and development. The tenures of Buhari (1983-85), Ibrahim Babangida (1985-1993), and Sani Abacha (1993-1998) traced a downward spiral of repression, economic devastation, arbitrary rule, and the erosion of institutions as the military, the central bureaucracy, with poor services and infrastructure [39] and evidence of extra ordinary corruption. The worst thing about Babangida's regime was the abrogation of the democratic transition in June 1993, when it annulled the results of a presidential election that was widely regarded with hope of returning the country to civilian rule [40]. The ensuing crisis provoked widespread uncertainty, ethno regional antipathy, and further economic decline, inducing Babangida to depart and establishment of a Civilian Caretaker Committee. This was scrapped in a matter of weeks by the defence minister, General Abacha. Abacha behaved in an even more dictatorial manner than his predecessors. He contrived a political transition that would perpetuate his rule as a civilian president, and controlled the state security leading to the imprisonmentor murdering of politi- 
cal opponents. During Abacha's rule, the lack of fiscal discipline and rampant corruption left the economy in the doldrums. It is estimated that Abacha amassed a fortune of around US $\$ 6$ billion over four and a half years, which were largely diverted from state owned enterprises and projects or embezzled from the public treasury. This magnitude of plunder led to the accelerated decline of the education and health systems, public services, and utilities, and therefore had a large negative impact on the economy.

Furthermore, the accumulated plunder of preceding rulers manifested in a depleted treasury, a huge debt overhang, dilapidated public institutions, endemic corruption, and simmering social hostility, while communal violence exploded in a myriad of conflicts across the country [41]. A large political class shows little capacity to address the country's urgent economic and social challenges. The country therefore underwent constant political instability and conflicts, which undoubtedly was the most unfavourable context to transform oil revenues into some form of development. In addition, the policies of the governments were not sufficiently favourable and consistent in promoting the development of agriculture and the non-oil industry sectors [16].

Given such political environment, there is no doubt that Nigeria has a very weak legal regime, with conceptual representation of property to create value being absent from the legal framework. Economic development, as argued by classical theories, is based on aggregated factors of production capital, land, and other natural resources, in addition to labour or human capital. If these classical factors of economic development were enough, it may be asked why this has not led to development in places like Nigeria that have an abundance of resources. The explanation is that development will not occur unless legal and institutional analyses are taken into account [42]. Legal frameworks and regulatory institutions are absolutely vital to ensuring a well-developed economy. The key constraints to Nigerian development include poor security, extremely weak commercial judicial systems, a generally weak legal system, impunity, corruption, and an unviable regulatory framework [43]. These may be described as institutional constraints and there is no economic policy which could remove these constraints. Although macroeconomic policies are unquestionably important, there is a growing consensus that the quality of business regulation, and the legal institutions that enforce it, are a major determinant of development [42] [43].

Ologunla et al. [44] concluded that the institutions of Nigeria are not strong enough to manage revenue from oil exports extensively enough to have a positive impact on the economy. There is indeed a negative effect of oil dependence in Nigeria on economic growth, which calls for strong institutional quality to turn the resource curse of the country into a blessing. Other countries with abundant natural resources, such as Botswana and Norway (which is discussed later), have escaped the resource curse owing to their strong institutions [12]. Therefore, for developing countries in general, good governance, accountability, high government effectiveness, good regulation, and anti-corruption policies 
tend to link natural resources with high economic growth.

Until recently the political economy of Nigeria was a capitalist authoritarian regime, with political leaders not being accountable to citizens via competitive elections, suppressed freedom of expression, any criticism of the regime being severely punishable, and an atmosphere where secrecy in the affairs of state is routine. It is evident that oil in itself is not the curse, rather the unstable political system, weak institutions, inappropriate management of oil revenues and mismanagement of the rest of economy, are the curse in the case of Nigeria [45].

Indeed several factors undermined the translation of Nigeria's oil wealth into development. These are: political instability; widespread corruption; a lack of transparency and accountability; social unrest; conflict; disregard for due process and the rule of law, the weakening of institutions; and inequality in the distribution of wealth. Hence, this led the country to not benefit from its wealth. All of these are part of the problems enhancing the resource curse in Nigeria [15]. There is an urgent need for increased transparency and accountability in the management of Nigeria's oil revenues [20].

In summary, as an oil exporter, Nigeria has pursued a resource based growth strategy since independence but has been unable to achieve sustainable economic growth. High oil dependency has been the basis of economic growth in Nigeria since the 1960s. Between 1970 and 2000, and also more recently, growth rates were very volatile in much the same way as oil prices. Oil dependency has caused the Nigerian economy to become stagnant owing to its inability to diversify its economy. Furthermore, a nation's institutions are very important to its development, and therefore the quality of institutions play a crucial role to enhance the level of economic growth in the country. In this direction, there is significant correlation between the level of corruption in Nigeria and the country's ability to develop its economy positively. To address the issue of oil dependence, Nigeria could focus on diversification and industrialisation to promote economic growth, in addition to improving the quality of its institutions and maintaining a more stable political environment.

\section{Norway: The Case of a Resource Blessing}

Norway is the fifth largest oil exporter in the world, with a daily production capacity of 2.4 million barrels, which is the same level of output as Nigeria [46]. The country has the largest oil reserves in Western Europe, with 5.497 billion barrels of proven crude oil reserves as of 2015 [14].

Norway is a country which generally avoided the resource curse, and is often seen by other oil-rich countries as an example worthy to be emulated. Oil was discovered in 1969 and it has managed to successfully steer away from the resource curse by minimizing rent-seeking behaviours and corruption. Norway's production grew to one of the highest in the world. However, sudden oil revenue inflows did not affect the basic economic structure of country and did not unsettle industries in existence before the oil era. Moreover, Norway utilised its oil 
revenue to invest in long term economic growth [47] [48].

Norway was one of the poorest nations in Europe. The country had a large raw material based export industry, with investment predominantly deriving from foreign capital. But from this starting point, Norway proved able to combine economic growth and social development, even when the economy was exposed to the sudden emergence of two new energy sources; firstly hydropower and then oil. The exploration and utilisation of these sources would, to some extent, become enclaves in the Norwegian economic structure. Despite this and other elements of foreign dependency, Norway did manage to secure additional development blocks related to water power and oil.

Since the 1970s the Norwegian economy has become even more internationally oriented and heads the world in key economic, social and political indicators. Norway is ranked 1st out of 188 countries with regard to HDI. As shown in Table 4, Norway's HDI value has increased from 0.811 in 1980 to 0.944 in 2014, an average annual increase of about $0.45 \%$. Norway differs significantly from Nigeria in these metrics, and therefore implies that a country with well managed oil wealth will have positive effects on these metrics, and lead to higher performance.

Norway is a rich country with respect to per capita income, which was US\$66,141 in 2013 [49]. The population is about 5.137 million with unemployment being very low and stable between $2.3 \%-4.7 \%$ since 2003 , and is expected to remain lowover 2014-2016. It is estimated that 1 out of every 9 jobs in Norway are linked to the oil industry, and there is no person living under the poverty line [46]; in addition, Norway is a net external creditor and international aid donor. Norway experienced almost one and a half decades, from 1972 to 1986, of high inflation. As shown in Figure 3, inflation increased from 5.7\% in 1985 to $7.2 \%$ and $8.7 \%$ in 1986 and 1987 respectively but, except in 2008, this has stabilised since then. This could be attributable to a more efficient management of the oil wealth, limiting its impact on prices.

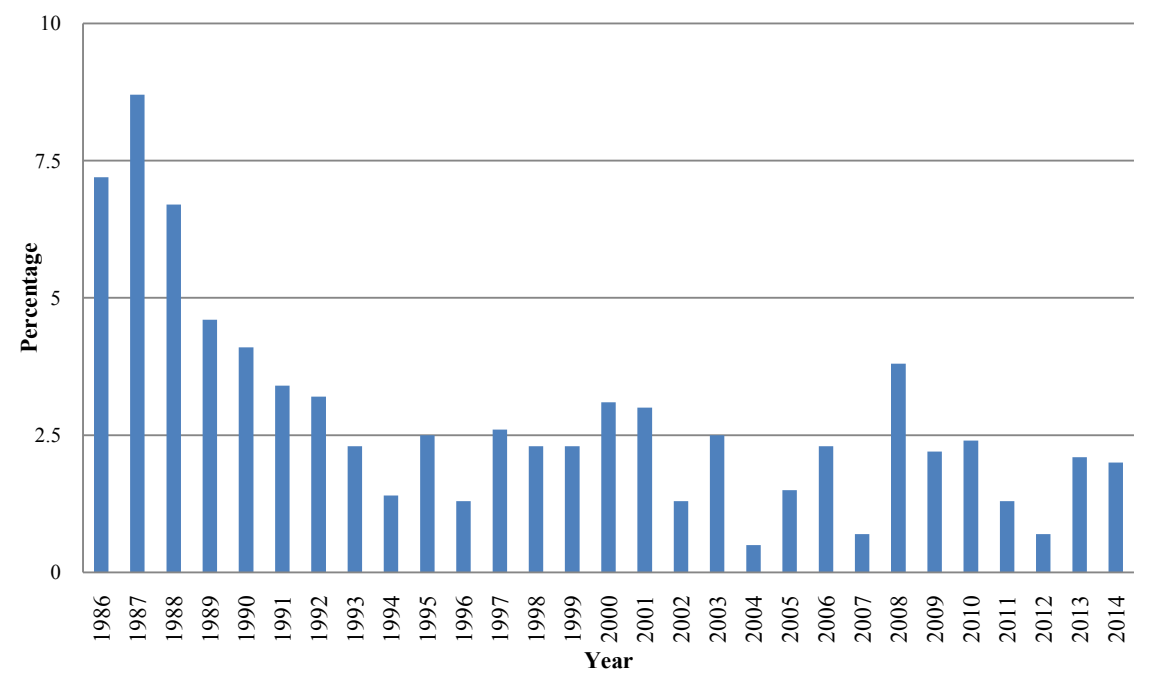

Figure 3. Norway inflation rate (CPI measurement) (1986-2014). Source: [49]. 
Table 4. Norway-Selected Human Development Indicators (HDI).

\begin{tabular}{lccccc}
\hline Year & $\begin{array}{c}\text { Life expectancy at } \\
\text { birth }\end{array}$ & $\begin{array}{c}\text { Expected years of } \\
\text { schooling }\end{array}$ & $\begin{array}{c}\text { Mean years of } \\
\text { schooling }\end{array}$ & $\begin{array}{c}\text { GNI per capita } \\
(2011 \text { PPP\$) }\end{array}$ & HDI value \\
\hline $\mathbf{1 9 8 0}$ & 75.6 & 13.1 & 10.3 & 34,076 & 0.811 \\
$\mathbf{1 9 8 5}$ & 75.9 & 13.2 & 10.9 & 40,052 & 0.828 \\
$\mathbf{1 9 9 0}$ & 76.5 & 14.0 & 11.5 & 42,152 & 0.849 \\
$\mathbf{1 9 9 5}$ & 77.7 & 15.6 & 11.8 & 50,017 & 0.883 \\
$\mathbf{2 0 0 0}$ & 78.7 & 17.5 & 12.0 & 57,853 & 0.917 \\
$\mathbf{2 0 0 5}$ & 79.9 & 17.5 & 12.3 & 64,151 & 0.931 \\
$\mathbf{2 0 1 0}$ & 81.0 & 17.5 & 12.6 & 63,578 & 0.940 \\
$\mathbf{2 0 1 1}$ & 81.1 & 17.6 & 12.6 & 63,327 & 0.941 \\
$\mathbf{2 0 1 2}$ & 81.3 & 17.5 & 12.6 & 64,926 & 0.942 \\
$\mathbf{2 0 1 3}$ & 81.4 & 17.5 & 12.6 & 64,283 & 0.942 \\
$\mathbf{2 0 1 4}$ & 81.6 & 17.5 & 12.6 & 64,992 & 0.944 \\
\hline
\end{tabular}

Source: [22].

Norway's example also demonstrates the wisdom of "leaving the oil underground" argument. Keen to avoid the Dutch disease and job losses in other industries, the authorities were reluctant to move forward too quickly and they kept offering direct support to the non-oil sectors. Licensing activity from 1969 to 1978 was relatively restrictive, and an abundant hydroelectric power supply meant that energy needs were less dependent on the new oil discoveries [47]. It was considered important to strike the right balance between developing the oil industry and other domestic industries, putting in place appropriate institutions, policies, and human capital to deal with the new windfall revenue. At the same time, spending increased through subsidies on agriculture and industry.

Norway is a small open economy, which is indeed rich in resources including oil, gas, hydropower, and minerals. But its other significant industries are shipbuilding, paper products, electronics, timber, textiles, and fishing, an indication of a highly diverse economy. The oil sector constitutes about a quarter of GDP and one third of total government income [50]. Its GDP amounted to US\$499.8 billion in 2014, with an annual growth which averaged at 3.5\%. The ratio of oil and gas to total exports accounts for just $21 \%$, with exports exceeding imports and there are extensive social welfare programmes.

The management of the petroleum resources reflects the view among Norwegian decision makers that the resources belong to the nation, and that the development of the industry should benefit society as a whole including future generations. This ambition was challenging for several reasons. The oil revenues are temporary, as they are based on a non-renewable natural resource. Furthermore, they are highly volatile, due to fluctuations in the oil price and uncertainty in the size of the resources. Thus, extraction should be undertaken at a moderate pace to ensure that wealth generated from these resources is saved for the future. 
Therefore, the policies for the management and spending of the petroleum wealth have assumed more importance, with the establishment of the Petroleum Pension Fund in 1990 and the adoption of the fiscal rule in 2001. The fiscal rule was that the spending of oil revenues should be equal to the expected real return from the Pension Fund. Therefore, this rule would enable the government to run with a permanent non-oil budget deficit, allowing for higher public spending and/or lower taxes than would have been possible without the oil revenues [51] [52]. The Pension Fund and the fiscal rule was to ensure that the large, volatile, and temporary net cash flow from the petroleum sector is transferred to a stable supplement to the government budget. Thus, the oil revenues allow higher public spending and/or lower taxes than would otherwise have been possible for the entire future.

Norway, as a successful oil rich country, shows that efficient institutions can turn natural resource into blessing, whilst Nigeria's experiences are a clear example of the resource curse. Unlike any other country that has discovered oil wealth, Norway had a modern welfare state in place before oil became a key source of wealth for the country. The welfare state became one of the institutions that secured a broad distribution of the benefits from oil production. Norway has a small population and already had a functioning representative democracy with strong institutions when it discovered oil. The Norwegian judicial system enjoys high levels of public trust and has a long-standing reputation of independence, competence and integrity. Furthermore, the judicial system is among Norway's least corrupt institutions [53]. Such rule of law plays a crucial role for economic development, and therefore can help turn the natural resource curse into a blessing, and is evident in the high quality of life and well-being in Norway.

Norway is also politically stable. Its political leaders are accountable to the public and are largely free from corruption. Norway is generally viewed as a non-corrupt country as shown in Figure 4. In 2014 it was ranked as the third least corrupt country in the world out of 191 countries [34]. It is one of the few resource-rich countries that have managed to escape the resource curse, using its oil and gas to achieve high standards of living for all its citizens rather than for the benefit of elites.

Norway indeed already had strong institutions when it discovered oil. This gave the countrya unique starting point, and with all this in place it has managed to distribute its oil wealth to its citizens. It has been able to counteract the resource curse and the "grabber-friendly" or rent seeking activities that are usually associated with the curse. Mehlum, et al. [10] mentioned Norway as an example of how good quality institutions may lead to an escape from the curse. Larsen [12] [47] also argued that good institutions are one of the main reasons for the escape from the curse as does most empirical studies [54] [55] [56] [57] [58]. Mehlum, et al. [56] study on mineral rent and social development in Norway also showed that natural resources in Norway kept the economy growing because oil discovery stimulated productive forces rather than "grabber-friendly" 


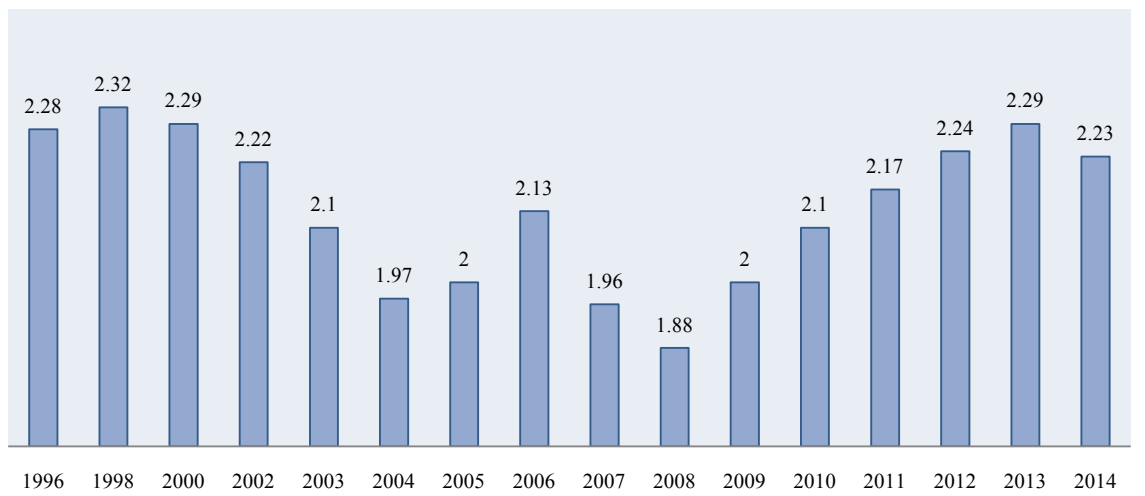

Figure 4. Norway Control of Corruption Index (1996-2014). Source: [34].

activities. This was as a result of high quality institutions and technological changes of oil extraction. Over the past two decades, Norway has transformed oil and gas resources into financial wealth. Oil revenues are invested abroad through a Sovereign Wealth Fund, which is managed by the central bank of Norway and in a highly transparent manner. It invests exclusively abroad to promote exchange rate stability, and to shield the Norwegian economy from the effects of oil-price fluctuations. Its Pension Fund is Europe's largest, and lags behind only that of the United Arab Emirates amongst those managed by governments [59]. Through investing in the name of future generations, the state has been able to absorb $80 \%$ of the resource rent [55]. The Government Pension Fund collects the net cash flow from petroleum activities and the return on its investments, which is then used to finance the government's fiscal deficit. The Norwegian government has taken a long-term view regarding its management of their natural resource wealth and sharing this wealth with its citizens.

Norway has successfully avoided the resource curse for several reasons. It has had a history of natural resource management that included integrating natural resource-based industries with the rest of the economy through various linkages. Furthermore, Norway's institutions were developed to handle shocks to the economy that are endemic to resource production, such as large changes in terms of trade. Also, the separation of rents based on natural resource extraction from the spending of these rents has gradually led to the establishment of a buffer fund that helps to create a more stable economic environment. The diversification of the economy leading to a reduction in the dominance of the oil sector was also essential to escaping from the resource curse, and therefore shocks in oil prices have had comparatively limited impact on the economy.

\section{The UAE: A Case of a Successful Development via Oil}

The United Arab Emirates (UAE) is the second largest oil producer in the Middle East, exporting the equivalent of 3.5\% of the total global oil production. Oil was discovered in 1958, when the seven separate emirates had the same under-developed economies that depended mainly on subsistence agriculture, nomadic animal husbandry, the extraction and trade of pearls, fishing, and seafar- 
ing. The period before the discovery of oil, therefore, reflected the country's limited natural resources, and resulted in a simple subsistence economy.

Oil exports started in 1962, with the era of economic development beginning in the early 1970s. The establishment of its formal economic, social, and political institutions, coinciding with a massive increase in oil production and oil exports, followed the explosive rise in oil prices in 1973. The major development of the country started in the early 1990s. Since the early 1970s the UAE's phenomenal growth has depended largely on the discovery and exploitation of oil. The oil and gas industries are well managed and the latest technology is continuously harnessed to increase production efficiency [60] [61].

In 2015, proven oil reserves in the UAE were 98.8 billion barrels, approximately $10 \%$ of the World's total and the third largest oil reserves in the world after Saudi Arabia and Iraq. The country also holds the fourth largest reserves of natural gas in the world. Such huge reserves could sustain long-term economic growth in the country. Today, the UAE is a major international tourist and business centre as well as one of the most modern, stable and safe countries in the world [62].

Since its independence in 1971, the UAE has enjoyed political stability. Existing political structures appear to reflect the tribal society of the UAE. The distribution of large oil revenues in the form of social and economic infrastructure, high salaries, and high standard of social services, such as health and education, has raised the standard of living for UAE citizens and considerably reduced the likelihood of internal political and social unrest. Political and social stability has gone hand in hand with liberal trade policies and has paved the way for investment, domestically and internationally in the industrial sector. In addition, corruption is a low risk for companies in the UAE as it is the least corrupt country in the Arab world [35]. The UAE offers a business-friendly environment, with an effective and efficient public administration. It is ranked 30th out of 191 countries for their control of corruption [34]. This is one important factor in avoiding the resource curse. Figure 5 shows the UAE's control of corruption score from 1996 to 2014 . It's mean score was 0.89 points, with a minimum of-0.09 points in 1996 and maximum of 1.29 points in 2013 [34].

The HDI value for UAE in 2014 was 0.835 , which placed the UAE in the high human development category and is ranked 41st out of 188 countries. From 1990 to 2014, the UAE HDI value increased from 0.726 to 0.835 , an increase of $15.1 \%$ or an average annual increase of about $0.59 \%$, as shown in Table 5 . It can be observed that the UAE has made progress in each of the HDI indicators. Between 1980 and 2014, the UAE's life expectancy at birth increased by 9.4 years, mean years of schooling increased by 5.9 years, and expected years of schooling increased by 4.7 years. The GNI per capita significantly decreased by about $42 \%$ between 1990 and 2014 although the country's per capita GDP is on par with those of leading nations at nearly US $\$ 25,000$. There are many factors accounting for this decline, such as inflation, the level of oil production and a rapidly increasing population [63]. The UAE's ranking was remarkable given the decline 


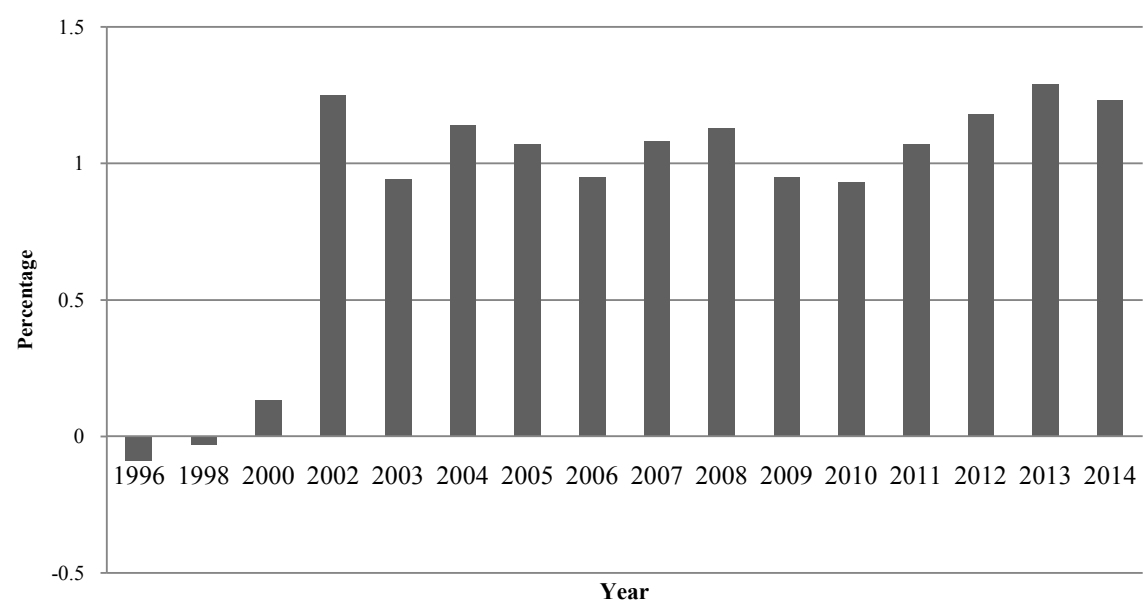

Figure 5. UAE Control of Corruption Index (1996-2014). Source: [34].

Table 5. UAE Human Development Index indicators.

\begin{tabular}{cccccc}
\hline Year & $\begin{array}{c}\text { Life expectancy } \\
\text { at birth }\end{array}$ & $\begin{array}{c}\text { Expected years } \\
\text { of schooling }\end{array}$ & $\begin{array}{c}\text { Mean years of } \\
\text { schooling }\end{array}$ & $\begin{array}{c}\text { GNI per capita } \\
\text { (2011 PPP })\end{array}$ & HDI value \\
\hline $\mathbf{1 9 8 0}$ & 67.6 & 8.6 & 3.6 & & \\
$\mathbf{1 9 8 5}$ & 69.8 & 9.8 & 4.5 & & \\
$\mathbf{1 9 9 0}$ & 71.5 & 10.6 & 5.6 & 104,901 & 0.726 \\
$\mathbf{1 9 9 5}$ & 72.9 & 11.2 & 7.1 & 105,505 & 0.763 \\
$\mathbf{2 0 0 0}$ & 74.2 & 11.9 & 8.3 & 109,644 & 0.797 \\
$\mathbf{2 0 0 5}$ & 75.4 & 12.7 & 9.0 & 103,840 & 0.822 \\
$\mathbf{2 0 1 0}$ & 76.3 & 13.3 & 9.5 & 56,624 & 0.828 \\
$\mathbf{2 0 1 1}$ & 76.5 & 13.3 & 9.5 & 56,208 & 0.829 \\
$\mathbf{2 0 1 2}$ & 76.6 & 13.3 & 9.5 & 57,078 & 0.831 \\
$\mathbf{2 0 1 3}$ & 76.8 & 13.3 & 9.5 & 59,124 & 0.833 \\
$\mathbf{2 0 1 4}$ & 77.0 & 13.3 & 9.5 & 60,868 & 0.835 \\
\hline
\end{tabular}

Source: [22].

in gross national income. This is probably because of the country's significant performance in health and education. Now the UAE is a hub of business and culture, and it has therefore used its wealth very wisely to promote its economy.

In spite of its high oil reserves, the UAE is no longer solely reliant on oil and gas revenues. Oil production currently makes up about one third of the GDP and $80 \%$ of national revenues are derived from oil [64]. The country experienced an average growth of 5\% between 1995 and 2004 [65]. Oil is therefore the foundation of the country's economy but it cannot be said that the economy of the UAE is overly dependent on oil. The majority of the revenues derived from oil are invested by the government into infrastructure and non-oil sector development projects.

The UAE neutralises the resource curse and Dutch disease by pegging its currency to the US dollar and investing heavily in modern infrastructure and edu- 
cation [66] [67]. Several strategies and policies adopted by the UAE have enabled the country to succeed in the process of development via oil. A few of these are discussed below.

Substantial amounts from oil revenue windfalls were invested by the government of the UAE into infrastructure improvements, such as airports, seaports, and roads [68]. Heavy investments into physical infrastructure hold promise of even more dynamic economic and business prospects. The government of the UAE takes advantage of the strategic location of the country with 15 seaports, through which goods and raw materials are exported and imported. Furthermore, these ports are used for the redistribution of goods and materials from and to countries in the MENA region and those of the Indian subcontinent [64].

The UAE government has reduced its dependency on oil exports by diversifying the economy, creating booming businesses, encouraging tourism, and development of the construction sectors. Although the UAE remains somewhat oil dependent, it is the least vulnerable to oil price or export volume declines amongst the Gulf countries. Therefore, the UAE economy appears the most diversified in the Gulf countries [69]. It is estimated by some economists that over the last three decades the UAE has invested around US $\$ 7$ billion in its industrial development and established over 1000 factories [70]. The dominant industries are petrochemicals, other chemicals, hydrocarbons, and plastics owing to the country's oil supplies. Over the last decade, the non-oil sector experienced a 9\% annual growth. That is the direct consequence of the UAE's government's commitment to the economic diversification away from oil dependence policies [71]. In addition to the above listed industries, the other sectors developed include fertilisers, cement, tourism, trade and manufacturing, real estate, construction, and financial services [64]. Whilst oil production makes up about one third of its GDP, the ratio of new non-oil industries to GDP has increased significantly over the last decades.

A World Bank [71] report indicates that the UAE achieved significant progress in economic development due to its commitment to trade and openness, including the introduction of free trade zones and economic diversification policies. In addition, the government of UAE favours foreign direct investment and has also encouraged companies to invest in manufacturing by offering low interest rate loans through the Emirates Industrial Bank [68].

The government prioritises the establishment of knowledge economy, and that is intended to become the "backbone" of the economy. Education and innovation are expected to play a major role in increasing productivity and competitiveness. There are a number of successful innovation based initiatives which adds to the growth of the country's economy and creates employment. Recently, Dubai Internet City succeeded in attracting high profile technology companies, such as Microsoft, Oracle, and Hewlett-Packard [64]. Development led and supported by the government's economic policy reforms and streamlined foreign investment regulations are contributing to an exemplary growth of the UAE 
economy [68].

In contrast, the employment pattern in the UAE does not reflect the structure of output. The oil sector employs only $1.6 \%$ of the UAE labour force, reflecting the capital-intensive nature of the industry. Unemployment rate in the UAE is approximately $0.5 \%$, which means that the UAE economy is effectively at full employment. This has been attributed to the cluster of public services, transportation, communications, financial markets, and service-based industries in the cities.

The UAE is considered to have stable economic growth in the Middle East and is not directly threatened by any global crises at the moment. It's currency, the AED (Dirham), which is pegged to the USD helps to stabilise the currency but it also implies that a fall in the USD would erode its purchasing power in relation to imported goods that the country is so dependent upon [72]. The government is very aware of this problem and are trying to tackle it with initiatives, such as freezing prices on water, electricity, and everyday consumer goods. As shown in Figure 6, inflation rate has been under control since 2009, especially when compared to 2007 and 2008 [49]. The control of inflation is indispensable in securing its labour force, ensuring that workers still find it economically attractive to live and work in the UAE. The country has become an important financial centre due to its significant financial and services industries. It has emerged as the most important economy in the region, as the country has an ambition to be the financial and service sector leader in the Middle East.

It is clear from the above that political leaders of the UAE prioritise economic diversification away from oil generally. Furthermore, the political environment is stable, proactive, and progressive for furthering economic growth and innovations [64]. Despite the fact that the current government is not democratic, and that political turmoil is present in the region, the UAE are politically stable and at low risk, as they are focused on economic development as their prime political objective [68].

But there are still enormous social and economic gaps within the UAE. Firstly, the regional inequalities in terms of development among the seven Emirates of the UAE; $50 \%$ of total manufacturing is concentrated in Abu Dhabi, and when

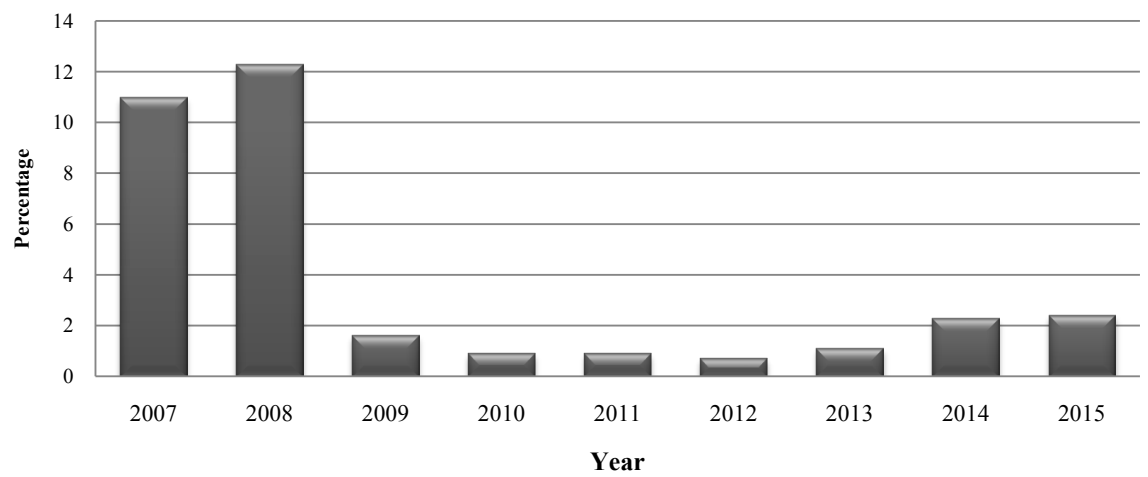

Figure 6. UAE inflation rate (CPI measurement) (2007-2015). Source: [49] [73]. 
combined with Dubai and Sharjar, output reaches $93 \%$ of all industrial production [70]. Abu Dhabi also represents $80 \%$ of total non-oil trade in the country [64]. The other four Emirates have little oil, accounting for only 6.9\% of GDP. They are heavily dependent on subsidies from the UAE central government. Although the UAE is politically stable, the potential for tension and conflict is there if the gap in wealth among the Emirates is not addressed [74]. Social policies issues lead to inequality. While many basic social services are provided to expatriates at reduced rates, UAE citizens get salaries roughly double of those of expatriates in similar jobs and have access to numerous subsidies, grants, loans, and free services which are unavailable to expatriate workers. High levels of immigration have resulted in migrant workers comprising more than three quarters of the population. The UAE has reaped benefits from foreign skilled and unskilled workers who initiated its economic development in the early 1970s, and subsequently have come to sustain it. Thus, a small indigenous population, a large migrant population, and immense wealth generated by oil are the dominant socio-economic features of the UAE.

\section{Concluding Remarks}

This paper has focused on Nigeria, Norway, and the UAE regarding the effects of abundant natural resources on their economies. In both the political and economic realm, the main indicators of success or failure have been discussed. That is, an evaluation of the economics and political nature of the natural resource curse with a brief assessment of likely outcomes in the three case studies.

The policies of Norway and UAE were successful in moving the economy from its full dependence on a single sector, the oil sector, to depending on multiple sectors and resources, while Nigeria failed to diversify its economy away from oil dependency. As seen in the case of Norway, the oil discovery led the country to become one of the most developed countries. In contrast, Nigeria, which started its oil boom in 1970, has instead become highly dependent on oil revenues.

Using the corruption index as a measure of institutional quality, Norway ranks third out of 191 countries evaluated in 2014 and the UAE's ranks $30^{\text {th }}$.By contrast, Nigeria is positioned at $177^{\text {th }}$. This indicates a very high level of corruption risk, owing to the lack of overall transparency, having no anti-corruption plan in place, and significant opaque off-budget expenditures. Norway has avoided the resource curse while Nigeria has experienced a classic case, with the latter's outcome attributed to poor policy choices.

Nigeria, a major oil exporter in Africa with a fifty-year history of oil exportation, is still experiencing the resource curse in its pure form. Almost $90 \%$ of its GDP total exports are oil. The country is dependent on food imports, the non-oil industries are almost non-existent and the vast majority of the population lives under the poverty line. The causes for these lie in excessive public spending, mismanagement of boom and bust cycles with unrealistic financial projections, 
consequent borrowing abroad and debt servicing, low demand in domestically produced goods, and lack of government investment in infrastructure and non-oil sectors. Oil production and exports operate in a constantly unstable political environment with weak institutions, along with widespread corruption, absence of accountability, and transparency in managing oil revenues. These negative and detrimental effects prevail over developmental prospects in Nigeria.

Norway utilises its oil revenue influxes into long term and sustained development; the economy is highly diverse. Growth rates are steady and rather high, its citizens enjoy one of the highest living standards in the world, and there is no person living under the poverty line. The reasons Norway managed to reverse negativities and turned oil into an economic and social blessing are found in generally sound economic policies, focused on stabilising inflation, creating employment, building vast financial reserves abroad in the form of Sovereign Wealth Funds so as to shield the economy from oil price fluctuations. The mature democracy and stable political system, with good institutions, accountability, and transparency in managing oil wealth, are of paramount importance in turning oil reserves of Norway into a blessing for the country.

Currently, the UAE is undergoing a remarkable process of development through oil revenues. Although oil is the foundation of the UAE economy, just a third of GDP is derived from oil. Economic growth is high, and the government invests highly in infrastructure and non-oil sector development projects. There is a continuous government commitment to economic diversification, open and free trade, favourable conditions for foreign investment, as well as prioritisation of education, innovation, and creation of a knowledge economy. The other factors adding to UAE's success story is that the political system, whilst not democratic, is stable. The government establishes development as the prime political objective and is the key and active actor in the process of development via oil. Yet, in spite of all positive developments, the UAE is still to address the challenges of inequalities based on territory, nationality, and gender.

The assessment in the paper clearly shows that resource-rich countries, especially developing ones, have possible options to follow, in terms of policy and institutional setups in avoiding the resource curse and turning that into a blessing for the benefit of current and future generations. A possible extension of this paper is a more robust quantitative comparative assessment of the three countries, especially relating to the role of institutions in natural resource curse, to validate conclusions made here.

\section{References}

[1] Boyce, J.R. and Emery, J.C.H. (2011) Is a Negative Correlation between Resource Abundance and Growth Sufficient Evidence That There Is "Resource Curse"? Re sources Policy, 36, 1-13. https://doi.org/10.1016/j.resourpol.2010.08.004

[2] Bulte, E.H., Damania, R. and Deacon, R.T. (2005) Resource Intensity, Institutions, and Development. World Development, 33, 1029-1044.

https://doi.org/10.1016/j.worlddev.2005.04.004 
[3] Freeman, D.G. (2009) The "Resource Curse" and Regional US Development. Applied Economics Letters, 16, 527-530. https://doi.org/10.1080/13504850601032107

[4] Sachs, J.D. and Warner, A.M. (2001) The Curse of Natural Resources. European Economic Review, 45, 827-838. https://doi.org/10.1016/S0014-2921(01)00125-8

[5] Auty, R.M. (1998) Resource Abundance and Economic Development: Improving the Performance of Resource-Rich Countries. UNU World Institute for Development Economics Research, Helsinki.

[6] Sachs, J.D. and Warner, A.M. (1995) Natural Resource Abundance and Economic Growth. Paper No. 5398, National Bureau of Economic Research (NBER).

[7] Corden, W.M. and Neary, J.P. (1982) Booming Sector and De-Industrialisation in a Small Open Economy. The Economic Journal, 92, 825-848. https://doi.org/10.2307/2232670

[8] Corden, W.M. (1984) Booming Sector and Dutch Disease Economics: Survey and Consolidation. Oxford Economic Papers, 36, 359-380. https://doi.org/10.1093/oxfordjournals.oep.a041643

[9] Karl, T.L. (2007) Oil-Led Development: Social, Political, and Economic Consequences. CDDRL Working Papers, 80, $36 \mathrm{p}$.

[10] Mehlum, H., Moene, K. and Torvik, R. (2006) Institutions and the Resource Curse. The Economic Journal, 116, 1-20. https://doi.org/10.1111/j.1468-0297.2006.01045.x

[11] Mehlum, H., Moene, K. and Torvik, R. (2006) Cursed by Resources or Institutions? The World Economy, 29, 1117-1131. https://doi.org/10.1111/j.1467-9701.2006.00808.x

[12] Larsen, E.R. (2006) Escaping the Resource Curse and the Dutch Disease? American Journal of Economics and Sociology, 65, 605-640. https://doi.org/10.1111/j.1536-7150.2006.00476.x

[13] (2014) Worldwide Look at Reserves and Production. Oil \& Gas Journal, 112.

[14] OPEC (2015) Organization of the Petroleum Exporting Countries (OPEC): Annual Statistical Bulletin.

http://www.opec.org/opec_web/static_files_project/media/downloads/publications/

[15] Ogwumike, F.O. and Ogunleye, E.K. (2008) Resource-Led Development: An Illustrative Example from Nigeria. African Development Review, 20, 200-220. https://doi.org/10.1111/j.1467-8268.2008.00182.x

[16] Ugochukwu, C.N.C. and Ertel, J. (2008) Negative Impacts of Oil Exploration on Biodiversity Management in the Niger De Area of Nigeria. Impact Assessment and Project Appraisal, 26, 139-147.

[17] Partnership Initiatives in the Niger Delta (PIND) (2011) Palm Oil Value Chain Analysis in the Niger Delta: Wuse II. Foundation for Partnership Initiatives in the Niger Delta, Abuja.

[18] Omeje, K. (2006) The Rentier State: Oil-Related Legislation and Conflict in the Niger Delta, Nigeria. Conflict, Security \& Development, 6, 211-230. https://doi.org/10.1080/14678800600739259

[19] Junior, E.O. (2015) Analysis of Oil Export and Corruption in Nigeria Economy. International Journal of Economics, Commerce and Management, III, 112-135.

[20] Hjort, J. (2006) Citizen Funds and Dutch Disease in Developing Countries. Resources Policy, 31, 183-191. https://doi.org/10.1016/j.resourpol.2007.01.001

[21] NBS (2010) National Bureau of Statistics. http://www.nigerianstat.gov.ng/

[22] UNDP (2015) United Nations Development Programme (UNDP): Human Devel- 
opment Reports. http://hdr.undp.org/en/data

[23] NBS (2012) National Bureau of Statistic (NBS): Annual Abstract of Statistics. http://www.nigerianstat.gov.ng/pdfuploads/annual_abstract_2012.pdf

[24] IMF (2014) World Economic Outlook (WEO) Data. http://www.econstats.com/weo/V027.htm

[25] World Bank (2014) World Bank Data: Inflation, Consumer Prices (Annual \%). https://data.worldbank.org/indicator/FP.CPI.TOTL.ZG

[26] Bevan, D.L., Collier, P. and Gunning, J.W. (1999) The Political Economy of Poverty, Equity, and Growth: Nigeria and Indonesia. http://documents.worldbank.org/curated/en/118981468775569456/pdf/multi-page. pdf

[27] Iyoha, M.A. (1999) External Debt and Economic Growth in Sub-Saharan African Countries: An Econometric Study. African Economic Research Consortium (AERC), Nairobi

[28] Amakom, U.S. (2003) Nigeria Public Debt and Economic Growth: An Empirical Assessment of Effects on Poverty. African Institute for Applied Economics, Enugu.

[29] World Bank (2016) External Debt Stocks, Total (DOD, Current US\$). https://data.worldbank.org/indicator/DT.DOD.DECT.CD

[30] OECD (2012) Organisation for Economic Co-Operation and Development (OECD): African Central Government Debt 2012.

http://www.oecd-ilibrary.org/finance-and-investment/african-central-governmentdebt-2012_acgd-2012-en

[31] Sandbakken, C. (2006) The Limits to Democracy Posed by Oil Rentier States: The Case of Algeria, Nigeria and Libya. Democratisation, 13, 135-152. https://doi.org/10.1080/13510340500378464

[32] GFI (2017) Global Financial Integrity (GFI): Illicit Financial Flows to and from Developing Countries: 2005-2014.

http://www.gfintegrity.org/report/illicit-financial-flows-to-and-from-developing-co untries-2005-2014/

[33] GFI (2014) Global Financial Integrity (GFI): Illicit Financial Flows from Developing Countries: 2003-2012.

http://www.gfintegrity.org/report/2014-global-report-illicit-financial-flows-from-de veloping-countries-2003-2012/

[34] World Bank (2014) World Bank Databank: Worldwide Governance Indicators. http://databank.worldbank.org/data/databases/control-of-corruption

[35] Transparency International (TI) (2015) Corruption Perceptions Index 2015. https://www.transparency.org/cpi2015

[36] Jensen, N. and Wantchekon, L. (2004) Resource Wealth and Political Regimes in Africa. Comparative Political Studies, 37, 816-841. https://doi.org/10.1177/0010414004266867

[37] Ikpe, U.B. (2000) Patrimonialism and Military Regimes in Nigeria. African Journal of Political Sciencel Revue Africaine de Science Politique, 5, 146-162.

[38] Lewis, M.P. (2006) The Dysfunctional State of Nigeria. In: Birdsall, N., Vaishnav, M. and Ayres, L.R., Eds., Short of the Goal, US Policy and Poorly Performing States, Centre for Global Development, Washington DC, 83-116.

[39] Ukiwo, U. (2003) Politics, Ethno-Religious Conflicts and Democratic Consolidation in Nigeria. The Journal of Modern African Studies, 41, 115-138.

https://doi.org/10.1017/S0022278X02004172 
[40] Lewis, P.M. (1994) Endgame in Nigeria? The Politics of a Failed Democratic Transition. African Affairs, 93, 323-340. https://doi.org/10.1093/oxfordjournals.afraf.a098722

[41] Lewis, P. (1996) From Prebendalism to Predation: The Political Economy of Decline in Nigeria. The Journal of Modern African Studies, 34, 79-103. https://doi.org/10.1017/S0022278X0005521X

[42] Agbakoba, O. (2005) Development Law and Economic Reforms. http://olisaagbakobalegal.law/wp-content/uploads/2014/10/Development-Law-andEconomic-Reform.pdf

[43] Akinpelu, O.A. (2002) Corporate Governance Framework in Nigeria: An International Review. iUniverse, Bloomington, Indiana.

[44] Ologunla, S., Kareem, R. and Raheem, K. (2014) Institutions and the Resource Curse in Nigeria. Journal of Sustainable Development Studies, 7, 36-51.

[45] Ochogwu, J. (2006) Business and Conflict Management in Nigeria's Oil-Rich Niger Delta Region: From Forcible to Non-forcible Conflict Management (Dissertation). University of Bradford, Bradford.

[46] Hundley, T. (2007) Oil-Rich Norway Guards Its Wealth. The Seattle Times Company, Seattle, WA.

[47] Larsen, E.R. (2006) Escaping the Resource Curse and the Dutch Disease? When and Why Norway Caught Up with and Forged Ahead of Its Neighbours. The American Journal of Economics and Sociology, 65, 605-640.

[48] Spreng, D., Flüeler, T., Goldblatt, D.L. and Minsch, J. (2012) Tackling Long-Term Global Energy Problems: The Contribution of Social Science. Vol. 52, Springer Science \& Business Media, Zürich. https://doi.org/10.1007/978-94-007-2333-7

[49] World Bank (2015) Inflation, Consumer Prices (Annual \%). https://data.worldbank.org/indicator/FP.CPI.TOTL.ZG

[50] Walther, A. (2008) Energy for Development: Opportunities and Challenges. https://www.iea.org/media/weowebsite/workshops/subsaharanafrica/Ambassador Walther.pdf

[51] Holden, S. (2013) Avoiding the Resource Curse: The Case Norway. Czech University of Life Sciences, Prague.

[52] Aslanli, K. (2015) Fiscal Sustainability and the State Oil Fund in Azerbaijan. Journal of Eurasian Studies, 6, 114-121. https://doi.org/10.1016/j.euras.2015.03.004

[53] GAN Business Anti-Corruption Portal (2015) Norway Corruption Report. https://www.business-anti-corruption.com/country-profiles/norway

[54] Gylfason, T. (2001) Natural Resources, Education, and Economic Development. European Economic Review, 45, 847-859. https://doi.org/10.1016/S0014-2921(01)00127-1

[55] Gylfason, T. and Zoega, G. (2006) Natural Resources and Economic Growth: The Role of Investment. The World Economy, 29, 1091-1115. https://doi.org/10.1111/j.1467-9701.2006.00807.x

[56] Mehlum, H., Moene, K. and Torvik, R. (2012) Mineral Rents and Social Development in Norway. In: Hujo, K., Ed., Mineral Rents and the Financing of Social Policy, Social Policy in a Development Context, Palgrave Macmillan, London, 155-184. https://doi.org/10.1057/9780230370913_6

[57] Stevens, P. (2003) Resource Impact: Curse or Blessing? A Literature Survey. Journal of Energy Literature, 9, 3-42.

[58] Bornhorst, F., Gupta, S. and Thornton, J. (2008) Natural Resource Endowments, 
Governance, and the Domestic Revenue Effort: Evidence from a Panel of Countries. IMF Working Paper, Paper No. 08/170, 1-10.

[59] Alhassan, I. (2012) The Paradox of Plenty and the Resource Curse: The Case of Ghana.

http://thechronicle.com.gh/the-paradox-of-plenty-and-the-resource-curse-the-caseof-ghana/

[60] Shihab, M. (2001) Economic Development in the UAE. In: Al Abed, I. and Hellyer, P., Eds., United Arab Emirates. A New Perspective, Trident Press Ltd., London, 249-259.

[61] Waseem, Z. (2015) Achievements of the Union in UAE. https://prezi.com/0nxjz4j_65mi/achievements-of-the-union-in-uae/

[62] World Finance (2014) Banking Sector Integral to Sustaining UAE's Economic Future, Says UNB.

https://www.worldfinance.com/banking/banking-sector-integral-to-sustaining-uaes -economic-future-says-unb

[63] Ismail, K. (2010) The Structural Manifestation of the "Dutch Disease": The Case of Oil Exporting Countries. IMF Working Papers, Paper No. 10/103, 1-36.

[64] Grant, J., Golawala, F.S. and McKechnie, D.S. (2007) The United Arab Emirates: The Twenty-First Century Beckons. Thunderbird International Business Review, 49, 507-533. https://doi.org/10.1002/tie.20155

[65] World Bank (2018) GDP Growth (Annual \%). https://data.worldbank.org/indicator/NY.GDP.MKTP.KD.ZG?locations=AE

[66] Arezki, R. and Van der Ploeg, F. (2007) Can the Natural Resource Curse Be Turned into a Blessing? The Role of Trade Policies and Institutions. IMF Working Paper, Paper No. 07/55, 1-34.

[67] Ashby, T. (2008) Has the UAE Really Lifted the Curse of Resource Wealth? https://www.thenational.ae/business/has-the-uae-really-lifted-the-curse-of-resource -wealth-1.230320

[68] Kumar, H.M. (2008) UAE’s Oil Revenues.

[69] Hvidt, M. (2013) Economic Diversification in the GCC Countries: Past Record and Future Trends. Research Paper No. 27, Kuwait Programme on Development, Governance and Globalisation in the Gulf States, The London School of Economics and Political Science, London.

[70] United Arab Emirates. Encyclopedia of the Nations. http://www.nationsencyclopedia.com/economies/Asia-and-the-Pacific/United-Arab -Emirates.html

[71] World Bank (2003) MENA Development Report: Trade, Investment and Development in the Middle East and North Africa-Emerging in the World. Washington DC.

[72] Alami, A.E. (2013) A Study on a Currency Peg in the GCC Region with a Special Focus on UAE and Its Impact on Economic Development. The British University in Dubai, Dubai.

[73] Federal Competitiveness and Statistics Authority of UAE (2015) Statistics by Subject. http://fcsa.gov.ae/en-us/Pages/Statistics/Statistics-by-Subject.aspx

[74] Constantine, Z. (2007) Survey under Way on Poverty Levels in UAE. The Gulf News-Staff Reporter. 